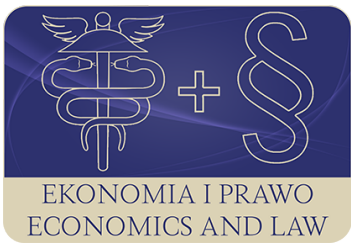

EKONOMIA I PRAWO. ECONOMICS AND LAW

Volume 19, Issue 4, December 2020

p-ISSN 1898-2255, e-ISSN 2392-1625

www.economicsandlaw.pl

ORIGINAL ARTICLE

received 13.03.2020; revised 22.05.2020; accepted 31.12.2020

Citation: Czupich, M. (2020). Inclusion in the implementation of public policy: the Polish experience. Ekonomia i Prawo. Economics and Law, 19(4): 639-656. doi:10.12775/EiP.2020.042.

\title{
Inclusion in the implementation of public policy: the Polish experience
}

\author{
MARIUSZ CZUPICH \\ Nicolaus Copernicus University in Torun, Faculty of Economic Sciences and Management, \\ Department of Economic Policy and Regional Studies, ul. Gagarina 13a, 87-100 Toruń, Poland \\ $\square$ czupich@umk.pl \\ D orcid.org/0000-0001-8009-9992
}

\begin{abstract}
Motivation: The concept of inclusive growth is considered as an instrument used to reduce many of today's developmental inequalities. It assumes, on the one hand, a reduction in the disparities in the level of income of society, and, on the other hand, the desire

to increase the standard of living. The latter aspect is particularly important in the socio-economic development policy at the regional and local levels. This is due to the possibility of participation and thus the impact of citizens on many dimensions of well-being, such as, health, safety or education. New public policy models provide such opportunities. They assume the involvement of a wide range of non-governmental actors in the planning and implementation of joint development activities.

Aim: The purpose of the article is to identify instruments for implementing the concept of inclusive growth in Poland. Particular emphasis was placed on social participation in the process of making public decisions in cities.

Results: Polish cities have been implementing the New Governance principles for over a dozen years, especially those regarding broad socialization of development policy. Examples include revitalization programs, hackathons and civic budgets, which create extensive opportunities for external entities to participate in public decision-making. Despite the fact that they show many limitations related to low attendance and social activity, they are treated as instruments for recognizing social needs and meeting them better. In

this context, they are consistent with the demands of the inclusive growth concept.
\end{abstract}

Keywords: inclusive growth; social participation; public policy; open government JEL: H770; O210; R130 


\section{Introduction}

Today, public authorities are facing dynamic and deep changes that affect the way in which development policy is conducted. These changes are becoming wider in scope and affect many socio-economic entities. They are shaped under the influence not only of various global trends but also on the national, regional, and local arena.

The most important development challenges and problems include the following:

- increase in social inequalities, such as, income disparities in society. Despite the use of many social policy instruments aimed at alleviating these inequalities, they are still large;

- restrictions in access to public services. What can be observed today is the worldwide tendency to migrate to cities. This causes a number of consequences for the functioning of cities, such as an increase in congestion, garbage production, water consumption, energy and $\mathrm{CO}_{2}$ emissions. Therefore, public authorities face many challenges in the areas of energy, waste, public space and transport management, as well as in administration;

- aging of the society. The increasing participation of older people in society poses further challenges for public authorities. They are related to the provision of effective healthcare, adaptation of transport, public space, and cultural offerings to the needs of these people, who often have disabilities. The aging of the society also reduces budget revenues with growing spending needs.

The challenges above lead to many questions about how to implement public policies:

- How to meet the new needs of citizens?

- How to identify the needs of different social groups?

- How to increase the effectiveness of public services with limited revenues?

The concept of inclusive growth is useful in this respect, which emphasizes not only the improvement of economic results but also non-income aspects of well-being, such as health and education, social connections, personal security, work-life balance, environmental quality of life (OECD, 2014). This concept draws more attention to reducing inequalities compared to the traditional approach to economic growth (Ali \& Son, 2007). It indicates that all members of society can participate in the process of growth (in decision-making) and the fair distribution of economic benefits. Therefore, inclusive growth means social participation and benefit-sharing (Boarini et al., 2015). Accordingly, participation in the light of the concept of inclusive growth can consist in the participation of society not only in the fair distribution of economic benefits but also in the process of planning and public management. The participation of a broad group of stakeholders favours linking public policy with real social needs. Public policy is becoming more efficient and public services more 
user-friendly and user-driven. Thus, inclusiveness becomes a critical dimension of effectiveness (OECD, 2015, p. 26).

The postulates of inclusive growth concern both macroeconomic policy (income improvement) and socio-economic policies implemented at the regional and local levels (quality of life). At these lowest levels, new public policy models, such as, for instance, New Governance, Government 3.0, are particularly applicable. Their characteristic feature is the open government approach (McDermott, 2010, pp. 401-413). It means a certain culture of action and public practices based on the principles of participation, transparency, accountability, which strengthen democracy and inclusive development (OECD, 2016, p. 25). Their fundamental element is the effective social participation. Research confirms that public administration and institutions, through cooperation with a wide range of stakeholders, become more representative, sustainable, and effective in resource management (Chatwin et al., 2019, p. 6). Therefore, new public policy models can be an instrument for implementing one of the postulates of the concept of inclusive growth related to social participation.

The research objective of the article is to identify instruments for implementing the concept of inclusive growth in Poland. Particular emphasis was placed on social participation in the public decision-making process in cities.

The article uses desk research to determine the essence of the concept of inclusive development as well as to identify the assumptions of the New Governance model and the benefits of public-private cooperation. Descriptive analysis, in turn, was used to present social involvement in revitalization processes, hackathons and civic budgets implemented in Polish cities. The analyses conducted made it possible to draw conclusions.

The article consists of three parts. The introduction is followed by the presentation of the essence of the inclusive growth concept. One of its postulates is broad social involvement in the implementation of public policy. The next part analyses the essence of the New Governance model and the benefits of social partners' participation in making public decisions. The last part of the article is a collection of case studies presenting examples of social participation in public activities. Various examples of revitalization, hackathons, and civic budgets implemented in Polish cities were provided.

\section{Inclusive growth: concept and essence}

The concept of inclusive growth is becoming increasingly popular in the world and is the subject of numerous studies and discussions (Bhalla, 2007, pp. 24-43; Klasen, 2010, pp. 1-23; Mello \& Dutz, 2012, pp. 1-290; Ramos et al., 2013, pp. 1-52). There is no single universally accepted definition of this concept. Rather, its diverse meaning and multi-faceted character are emphasized.

According to the OECD (2014, pp. 80-81), the idea of inclusive growth is based on the assumption that economic growth is not sufficient to improve society's well-being. A number of other aspects are also relevant, including health 
status, education, work-life balance, personal security and quality of life. Inclusive growth should be understood as economic growth that creates opportunity for all segments of the population and distributes the dividends of increased prosperity, both in monetary and non-monetary terms, fairly across society. Several aspects of this definition should be highlighted.

The first of these is multidimensionality. It is known that GDP only applies to economic welfare. Therefore, other dimensions of well-being, which include, among others, jobs, skills and education, health status, environment, civic participation and social connections, should also be taken into account. Secondly, in inclusive growth, the emphasis is laid on distribution. All people, regardless of their gender, ethnicity and race should be able to contribute to growth but should also be treated fairly in its division. Particular attention is paid here to the most discriminated groups, that is women and ethnic minorities, and their opportunities to participate in benefits. Thirdly, inclusive growth should have an impact on policies being implemented. Socio-economic policy instruments should be linked to these well-being dimensions. However, this requires an appropriate approach to policy making and the inclusion of different social groups in the decision-making process.

The World Bank, in turn, proposes a very general definition. According to this institution, inclusive growth allows people to contribute to and benefit from economic growth (Ianchovichina \& Lundstrom, 2009, p. 2). Attention is drawn to the fact that this increase should be understood in the long term because it should be based on an increase in employment productivity and not on a direct redistribution of budget revenues. The use of income distribution systems by governments to increase the income of excluded social groups is an ad hoc solution that leads to a significant burden on budgets and does not produce the desired results in some social groups.

Additional terminological problems relate to similarities and differences between inclusive growth and the concept of pro-poor growth. Both processes focus on reducing disparities in poverty and inequality. Therefore, they are often treated identically, as synonyms. Sometimes, however, the differences are emphasized by increasing the economic or non-economic aspects of society's well-being. The differences also concern the results and effects of the implementation of these two processes (Ranieri \& Ramos, 2013, pp. 1-25). Furthermore, inclusive growth is often referred to as 'people-centred growth'. All this makes it difficult to systematize terminology and meanings.

Moreover, there are proposals to distinguish between growth and inclusive development. Rauniyar \& Kanbur (2010, p. 4) claim that inclusive growth refers only to economic growth measured by per capita income, while inclusive development applies to other dimensions of human well-being (such as, education or health). The importance of equal distribution of benefits, both material ones and those concerning well-being, capabilities, social and political empowerment are emphasized (Hickey et al., 2015, p. 5). This process should also include creating relationships and encouraging joint activities. These activi- 
ties are directed not only to the poorer part of society but also to the 'non-poor' since their support contributes to sustain broader-based and more sustainable interventions (Nelson, 2003, pp. 119-138). Therefore, the concept of inclusive development is more widely understood than inclusive growth.

There are also many approaches to the methodology for measuring inclusive growth. According to Klasen (2010, p. 10), the reduction of income and well-being inequalities (education, health, nutrition, social integration) requires the following:

- positive per capita income growth;

- primary income growth rates (pre-tax income, self-employment income) of disadvantaged groups and areas (ethnic minorities, women, less developed regions, rural areas) at least as high as the per capita income growth rate;

- improvement of selected non-income dimensions of well-being for disadvantaged groups to an extent exceeding the average rate;

- improving indicators on learning and survival (e.g., mortality of children aged 1-5), improving nutrition, access to transport, communication, public services (e.g., clean water, garbage collection).

One of the most popular proposals for measuring inclusive development is the Inclusive Development Index based on a set of 12 variables developed by the World Economic Forum (2018, p. 2) (table 1). This methodology is used to calculate and rank countries by the level of their inclusive development. The ranking has been developed in two versions: one for advanced economies and the other for emerging ones. In 2018 the most inclusive countries were Norway, Iceland and Luxembourg. In turn, Lithuania, Hungary and Azerbaijan turned out to be the best in the emerging economies groupl.

In summary, inclusive growth should, on the one hand, reduce economic inequalities and on the other hand, create new opportunities to improve living conditions. In this second aspect, the key role is played by the public authorities' openness to dialogue as well as providing citizens with the opportunity to articulate their needs and to actively participate in meeting them.

The article focuses on the possibilities of improving living conditions through the implementation of public policy open to the involvement of citizens. Public-private cooperation brings many benefits to all participants.

${ }^{1}$ Poland was ranked high in this group (in fifth position). Poland's strength was its economic results, including GDP per capita (USD 15,049), and labour productivity (USD $55,716)$. Also, Poland had a relatively good demographic load index (44.9\%), healthy life expectancy (68.7 years) and low poverty rate $(0.3 \%)$. Weaknesses included a low employment rate (53.2\%), high $\mathrm{CO}_{2}$ emission intensity (82.9 kg per USD of GDP) and high public debt (54.2\% of GDP) (World Economic Forum, 2018, p. 19). 


\section{Social involvement as a key element of the New Governance model}

The choice of instruments that will reduce social inequalities and bring greater development stability is a big challenge for public policy. One of the ways to implement socio-economic policy is incorporating non-governmental actors into the processes of planning and implementing public policies (Donahue \& Zeckhauser, 2011, pp. 4-5). The group of actors includes residents, enterprises, non-profit institutions, educational, research and healthcare institutions, etc.

The agreement of public institutions with external partners is characteristic of the 'New Governance' paradigm. This model of exercising power replaced the bureaucratic model called 'public administration', which was not adequate to the contemporary challenges of development (López-Santana, 2015; Newman, 2001). The list of characteristics of both types of exercising power is contained in table 2.

The New Governance concept clearly underlines external responsibility towards citizens and focuses on achieving specific results (Kożuch, 2007, p. 24). It also resulted in a greater exposure of citizens' participation in the decision-making process. Public authorities began to focus on optimizing public spending by using such elements of rational management as outsourcing, decentralization and management by objectives. It also caused changes in the criteria applied for assessing the activities of the public authorities. Increasingly, categories known to be far from the public administration, such as purposefulness, reliability, cost-efficiency and effectiveness, have been used.

The 'New Governance' paradigm emphasizes the operation of specific tools tailored to real needs rather than to programs as a whole. These tools are very flexible and innovative, especially since they are used by numerous external entities involved in various projects. In this way, a cooperation network is created in which each of the actors has their own competences, work ethos and organizational procedures. The combination of these potentials makes it possible to increase management efficiency and thus better meet the collective needs of residents.

Joint implementation of public tasks is related to the division of responsibility for the common good. The whole process should be supervised by regional authorities, although responsibility also lies with the performers of specific tasks. Cooperation encourages the creation of new ways of thinking and creative problem-solving. Despite the fact that the cooperation concerns representatives of various organizations, they form an integrated system together, become interdependent and their operation is holistic (Keast et al., 2004, p. 365). They are guided by a common mission and goals, striving to increase the efficiency of public tasks. In cooperation, synergy is created, which means that together public and private partners are able to achieve better results than they would alone. This is due to the combination of human, administrative and financial 
potential for joint actions. Collaboration makes it possible to use the knowledge of individual actors to find solutions to their problems.

Cooperation should not take place incidentally. Rather, it should be institutionalized and based on elements such as decentralization of tasks and their assignment to small groups, decreasing the hierarchy and creating flexible linkages for other interested parties. Only then is it able to bring positive results. Most important outcomes of collaborative dialogue include reciprocity (adaptation to joint actions to achieve a goal), relationships (building social capital, trust, tolerance, establishing contacts between partners), learning (joint development of a strategy allows acquiring new knowledge, learning new facts), and creativity (brainstorming, creating scenarios triggers new ideas) (Innes \& Booher, 2003, pp. 42-46). It is worth emphasizing that this is a win-win situation for both parties (Nurudin et al., 2015, p. 506). Authorities receive feedback about social needs, which is very helpful in better planning and implementing projects aimed at increasing the standard of living of residents. Moreover, participation also means that local residents are well informed about their policies, plans, programs and investments. In turn, the authorities receive public acceptance of spatial planning, public services and infrastructure activities. An additional aspect of residents' cooperation with their authorities is building trust in public institutions and increasing social integration and a sense of responsibility for the common good and the environment.

However, there are some limitations of New Governance. Firstly, in this model public selection is made mainly on the basis of collective action. This extends the decision-making process. Wide-ranging public consultations delay the moment of implementing the decision. Secondly, the desire to dominate and impose one's will on weaker groups may also be a threat to New Governance. Stronger actors can strive to use their advantage and gain individual benefits. Thirdly, for the model to be effective, a sufficiently high level of social capital is required. In the countries of Central and Eastern Europe (CEE), including Poland, where the socio-political system has changed relatively recently, this is problematic. That results from the fact that social relations, trust and subsidiarity are only just forming in society. Therefore, the network model of public governance does not yet have the necessary potential. Furthermore, there is low political culture in CEE, which results in the appropriation of individual administrative structures by political parties and low levels of leadership (Czachor, 2016, p. 75). This is not conducive to cooperation and opening to external entities. The above arguments mean that the implementation of the New Governance principles requires not only overcoming many organizational but also mental barriers.

Public governance with citizens' participation may also raise some controversy. This controversy is related to high costs of the decision-making process, its time-consuming nature, blurring of responsibility and taking into account the opinions and expectations of only the most active groups or entities (Pe- 
ter-Bombik \& Szczudlińska-Kanoś, 2015). Therefore, it should be concluded that the assumed results are not achieved in all cases.

Nevertheless, in many cases there are many barriers to overcome as part of public-private cooperation. These include institutional barriers, such as bureaucratic rules and routines, rigid budget and accounting systems, and control-oriented performance management tools (Agger et al., 2015, p. 7). Apart from them, there are also barriers resulting from a rigid perception of their roles that discourage public and private entities from engaging in the joint search for innovative ideas and solutions. Therefore, it is important to diversify forms of cooperation, systematically collect information from users, and involve experts. Only fair treatment of social partners brings measurable benefits. In the case of initial setbacks, the willingness to cooperate in the future decreases.

The importance of social participation in public policy depends on many factors. These include trust in public institutions, the level of development of a given region, the level of education of the inhabitants, the region's history, culture, tradition, etc. Research carried out in Europe has shown that there is a wide variation in the understanding and implementation of social inclusion. Considering this, three groups of countries can be distinguished (Banthien et al., 2003, pp. 47-48):

- Northern European countries - they can boast of a long tradition of cooperation between politicians and civil society organizations. This is expressed, among other things, in consultations and more advanced forms of participation. Especially in the Scandinavian countries, social partners play an active role in planning and management. They are not treated there only as suppliers of information.

- Southern European countries - in these countries there is no strong tradition of social participation in political decision making. It is rather a challenge for local and regional authorities.

- Central and Eastern European countries - in this group of countries civil society played a key role in political transformations in the late 1980s. Currently, an intensive development of both social organizations and forms of participation is underway. This process is accompanied by changes in legal regulations aimed at increasing the participation of residents in making public decisions.

Poland belongs to the last of the above groups. The experience related to the functioning of civil society is still scarce. The system transformation brought many changes in social and political life. There has been an increase in interest in public affairs. Furthermore, Polish cities regained organizational and financial autonomy only at the beginning of the 1990s. Therefore, new public management models have not been fully implemented yet. Despite this, in recent years, several instruments have been implemented that are aimed at social inclusion in the process of making public decisions. These activities aim to recognize social needs better, improve the efficiency of public tasks and, as 
a consequence, an increase in quality of inhabitants' life. In this way, Polish cities, though to a limited extent, implement the concept of inclusive growth.

\section{Collaborative actions in Polish cities: case studies}

When identifying the instruments for implementing the concept of inclusive growth in Poland, the questions posed in the introduction were taken into account. They concern the manner of implementing public policy towards contemporary development challenges:

- How to meet the new needs of citizens?

- How to identify the needs of different social groups?

- How to increase the efficiency of public services with limited revenues?

A review of activities undertaken by Polish city authorities with the involvement of citizens in recent years has been reviewed. Revitalization programs, public hackathons and civic budgets were selected in this way. These instruments confirm that the principles of the New Governance model related to the division of responsibility for the implementation of public tasks are being implemented in Polish cities.

They have a common denominator, namely they allow expressing the needs of various social groups living in cities and seeking for opportunities to satisfy them through public-private cooperation. Moreover, meetings with residents, discussions and consultations during the planning and implementation of these instruments direct the actions of municipal authorities towards the reduction of social problems. This is how the effectiveness of public policy implementation and the quality of life of residents are impacted.

These instruments mentioned are used on a different scale. Revitalization programs and civic budgets are implemented in a significant part of Polish cities, while hackathons are still of marginal importance and are rather rare. Nevertheless, they prove the innovativeness of city authorities in the form of satisfying social needs using new technologies.

\subsection{Revitalization programs}

Revitalization programs implemented by Polish cities constitute one of the instruments of implementing the concept of inclusive development. In 2015, the Polish government adopted a strategic document named National urban policy 2023, which included strategic goals and directions for the sustainable development of cities, creating jobs and improving the quality of life of residents. These goals included social participation and revitalization (Ministry of Economic Development, 2016). Revitalization is understood as the process of coming over the state of crisis in degraded areas that is carried out by revitalization stakeholders (i.e., city residents, entrepreneurs, informal groups, non-governmental organizations, public institutions, real estate owners, housing cooperatives) on the basis of a revitalization program. It focuses on those areas where negative social 
phenomena occur, such as, for instance, unemployment, poverty, crime, low level of education or social capital, insufficient level of participation in public and cultural life. Thus, the revitalization process primarily considers the need to improve the quality of life of residents, while modernization of infrastructure is only a complement to social activities. An example of such an approach is the organization of specialist training for the unemployed, as well as the renovation of the city common room and the purchase of multimedia equipment for the needs of these trainings. However, it should be emphasized that social goals are the most desirable result of revitalization. These include an increase in social activity, social recovery, reduction of poverty and social exclusion, increase of employment, development of entrepreneurship. The revitalization process is described in the so-called 'revitalization program', in which the degraded area, revitalization goals, project description, process management method, etc. are defined. The revitalization program is prepared by city and municipal authorities in Poland. They were obliged under the Act on revitalization (2015) to implement broad social inclusion in the process of preparing programs.

Participation of non-governmental actors is required at every stage of the activities carried out and it should take place through the forms of public consultation indicated in the Act on revitalization (2015). These include:

- collecting feedback in a paper or electronic form, including means of electronic communication, in particular, electronic mail or forms placed on the entity's website in the Public Information Bulletin;

- meetings, debates, workshops, study walks, surveys, interviews, using representative groups or collecting oral feedback.

At the same time, the Act on revitalization (2015) indicates that at least one form of consultation referred to in point one and at least two included in point two should be used in the entire revitalization process.

Local government authorities in Poland have been given the opportunity to finance the revitalization process from European Union funds. It has resulted in an increased interest in this issue and, consequently, the development of a significant number of regeneration programs.

Research conducted among Polish municipalities (including cities) showed that in 2017, 57\% of them carried out revitalization activities (GUS, 2018, pp. 45-48). In total, nearly 5,700 public consultation processes were carried out for the revitalization programs in force in 2017. It was obligatory to collect feedback either in a paper or electronic form. However, among the other forms of participation, meetings and surveys were most often organized. In total, 44,600 comments were collected. Altogether 285,000 people participated in these consultations, which translated into 203 people per one revitalization program on average. Most consultation participants were recorded in large cities.

Unfortunately, in small cities there was a low efficiency of social participation processes under revitalization programs. It turned out that even in small cities, which were characterized by an above average turnout in local elections, residents sporadically participated in social consultations in the field of revi- 
talization (Czupich, 2018). A narrow group of discussion participants deny the very idea of revitalization, which should be based on broad social participation in the local development process.

Another problem that was particularly visible in cities was the fact that the dominant type of applicant for revitalization projects were public entities, primarily city authorities and their subordinate municipal organizational units (Jarczewski \& Kułaczkowska, 2019, p. 16).

It is worth noting that providing a wide range of participants in the revitalization process participating in the discussion allowed substantive debate as well as building trust between public authorities and socio-economic partners.

\subsection{Public hackathons}

Hackathon is a combination of 'hack' and 'marathon'. Sometimes terms such as 'hackfest' (from the words: 'hack' and 'festival'), 'hackday' (if it lasts one day), 'code camp' or 'jam' are used. These are meetings of programmers, interface designers, graphic designers, entities interested in software development as well as citizens and organizations focused on creating new solutions. In Poland, hackathons are organized by governments in both large (e.g., Cracow, Warsaw) and medium-sized cities (e.g., Płock, Kielce). They take place according to a similar scheme. They take the form of a competition and usually last from several hours up to two-three days. The adopted form of competition also means that there is competition between small groups of programmers. The effect of these events is social innovations and new public solutions, often in the form of software applications that meet the expectations set by the organizers. Solutions are aimed at improving the quality of life of residents. Winners receive various types of prizes. These can be financial rewards or non-financial rewards (e.g., tickets, trips, tech prizes, internships). Moreover, marketing, advisory and financial support is often offered to develop the already created solutions.

An example of a hackathon is Hackathon City Coders Ptock, which the city authorities of Ptock (over 300,000 inhabitants) have been organizing since 2017. The organizers provide databases that are used by hackathon participants to develop new solutions. These are, among others, data on the location of road accidents in the city, investment areas, schools, bicycle stations, city monitoring.

The competition in 2019 gathered 31 teams of three each. They competed in a 40-hour hackathon, which focused on solutions to be implemented in the areas of urban public services, urban mobility and the promotion of ecology and safety for all generations. The winning team has developed an application for seniors. It allows older people to contact volunteers who will help them in their everyday problems. Additionally, it allows one to check the availability of medicines in pharmacies and call for help (Pleczyński, 2019).

In previous years, the awarded applications included information about areas where lawns are currently being mown - this information is intended for allergy sufferers to know which parts of the city are better to avoid in a given 
period, and a solution to check the queue in various departments of the City Hall as well as the ability to download a virtual number remotely (Mobility News, 2019).

Poland does not have much experience in organizing public hackathons because the first event of this type took place in 2016. However, taking into account global trends, it can be said that there will be more and more of them. Between 2017 and 2018, the number of global hackathons hosted on the HackerEarth Innovation Management Platform increased by 140\% (Joshi, 2019). The effect of hackathons organized by government organizations was 650 solutions in the field of public health, 243 solutions for risk management, 103 solutions for energy conservation and 72 solutions for smart cities. Social innovations created in this way strengthen the ability of individuals to act. Their foundation is the ingenuity of citizens, social entities, civil society, officials and entrepreneurs. It creates a specific ecosystem of social innovations that is an environment conducive to solving social problems.

\subsection{Civic budgets}

Civic (participatory) budgets are another dynamically developing instrument of participatory democracy used in Poland. They socialize the budgetary policy of cities. The participatory budget is one of the methods to decide on the spending of public funds. The idea of this budget is that local authorities make part of the municipal budget available to residents. Residents submit their projects to improve the quality of life. As a result of collective voting, the most desirable ones are chosen, which are then implemented by the city.

The advantage of participatory budgets over public consultations is that their results are binding for governments. They allow to meet the most felt needs of residents, integrate the local community and stimulate joint action.

There is no single, universally applicable civic budget model. Cities adapt this tool to the adopted goals and applicable conditions. This instrument was used for the first time in 2011 in the city of Sopot. The number of cities using indications of their inhabitants is growing very dynamically. In 2018, there were already 187. Since 2018, 66 cities with district rights (cities usually with more than 100,000 inhabitants) have had a legal obligation to implement civic budgets in the amount of at least $0.5 \%$ of all city expenditure. In other cities, it is a voluntary instrument. In 2018, in the two largest Polish cities - Warsaw and Cracow - the turnout in voting for the participatory budget amounted to approximately $5 \%$ of the entire population of these cities (Miasto 2077, 2019). In subsequent cities it was slightly higher: in Łódź - 16.4\%, Wrocław, Poznań and Gdańsk - about 10\%. On average, the turnout for entire Poland was 15\%. It is worrying that the interest in participating in this initiative has been falling, especially among young people. For example, in 2016 the average turnout in Poland was $23 \%$. The reason for this is the transfer of the entire process to the in- 
ternet. That is why some cities, such as Wrocław, have started discussions with residents about changes in the formula for organizing civic budgets.

Projects in civic budgets usually concern new roads, recreational and sports areas, paths and parking lots for bicycles, aesthetics and attractiveness of public space. After all, the needs are more significant than the possibilities of such budgets. The estimated costs of the proposed social projects in 2018 amounted to 1.2 billion PLN. Meanwhile, the total value of participatory budgets fluctuated around 161 million PLN, which equals 13\% of the reported needs (NIK, 2019). Other disadvantages of civic budgets are the lack of a link between the adopted projects and the city's development strategy, as well as the inefficient allocation of public funds.

\section{Conclusion}

In the face of growing disparities in the quality of life, aging of the population and problems with access to public services, there is a need to reform socio-economic policy, especially at regional and local levels. What is more, the pressure on the quality of existing public services is increasing and new needs are emerging (especially in crowded cities). One of the ways to reduce the above problems is to use inclusive growth instruments. This is especially important regarding the issue of social involvement in planning and implementing development policy.

Ample opportunities for social participation create new public policy models. In Polish cities, public authorities have been cooperating with social entities for several years in creating revitalization programs, hackathons and civic budgets. The benefit of this type of activities is a better recognition of the residents' needs and the implementation of solutions that improve their quality of life. An additional profit is the legitimization of public activities, increasing the efficiency of spending public funds as well as building trust and mutual relations.

Despite this fact, there are some barriers to the use of instruments of social participation in Poland. The largest of these is low attendance in both revitalization programs (especially in small cities) and participatory budgets. What is worse, in the latter the number of participants has been systematically falling for several years. This may indicate a lack of confidence in the authorities, too low budgets or the exhaustion of this formula of participation. Another problem was the low level of citizens' activity in submitting revitalization projects. Perhaps this was due to the belief that civil ideas have little chance of implementation because the demands of residents were rarely taken into account in the past by city authorities. Hackathons, in turn, are not yet popular among city authorities or residents. The organization of such events requires technical knowledge and assistance from ICT enterprises. Few Polish cities have shown initiative in this area in recent years.

In relation to the instruments for implementing the inclusive growth concept identified in Poland, some areas of further in-depth research can be indicated: 
1. Socialization of public policy is mostly due to legal provisions. This situation concerned revitalization programs and civic budgets in cities with district rights. A question arises here: what would cooperation with the community look like now, if it had not been imposed by relevant legal acts?

2. The society submitted many comments, ideas and suggestions in revitalization programs. It is worth examining how many of them were included in the later activities of city authorities. The low level of implementation of these comments will indicate that participation is apparent, and citizens will reduce their confidence in public authorities.

3. Hackathons are organized in Poland by a small number of cities. It may be due to difficulties in finding business partners, sponsors, etc. Perhaps some other barriers and restrictions prevent these events from happening. It is worth identifying them.

To sum up, social participation is becoming an increasingly popular instrument used in public management in Poland. In this way, local authorities allow citizens to take greater responsibility for the implementation of public tasks. However, it appears that the organization of revitalization programs, civic budgets and hackathons requires organizational and mental changes. City authorities should take greater account of the demands of external environments so that socio-economic development meets the expectations of citizens. However, one of the most urgent needs is the development of civil society, especially in shaping awareness and attitudes among local societies. Citizens' participation in city governance should result from a sense of responsibility for the common good.

\section{References}

Agger, A., Damgaard, B., Hagedorn Krogh, A., \& Sørensen E. (2015). Introduction. In A. Agger, B. Damgaard, A. Hagedorn Krogh, \& E. Sørensen (Eds.), Collaborative governance and public innovation in Northern Europe. Sharjah: Bentham Books. doi:10.2174/9781681080130115010004.

Ali, I., \& Son, H.H. (2007). Defining and measuring inclusive growth: application to the Philippines. ERD Working Paper, 98.

Banthien, H., Jaspers, M., \& Renner, A. (2003). Governance of the European research area: the role of civil society. Retrieved 22.01.2020 from http://ec.europa.eu.

Bhalla, S. (2007). Inclusive growth: focus on employment. Social Scientist, 35(7/8).

Boarini, R., Murtin, F., \& Schreyer, P. (2015). Inclusive growth: the OECD measurement framework. OECD Statistics Working Papers, 06. doi:10.1787/5jrqppxjqhg4-en.

Chatwin, M., Arku, G., \& Cleave, E. (2019). Defining subnational open government: does local context influence policy and practice. Policy Sciences, 52(3). doi:10.1007/s11077-018-09347-7. 
Czachor, R. (2016). Ewolucja paradygmatu współzarządzania (governance) i problemy w jego wdrażaniu. Zeszyty Naukowe Uczelni Jana Wyżykowskiego. Studia z Nauk Spotecznych, 9.

Czupich, M. (2018). Level of social participation in the creation of urban regeneration programmes: the case study of small towns in Poland. European Spatial Research and Policy, 25(2). doi:10.18778/1231-1952.25.2.05.

Donahue, J.D., \& Zeckhauser, R. (2011). Collaborative governance: private roles for public goals in turbulent times. New York: Princeton University Press. doi:10.1515/9781400838103.

GUS. (2018). Dane statystyczne z zakresu rewitalizacji na poziomie gmin. Retrieved 02.04.2020 from https://stat.gov.pl.

Hickey, S., Sen, K., \& Bukenya, B. (2015). Exploring the politics of inclusive development: towards a new conceptual approach. In S. Hickey, K. Sen, \& B. Bukenya (Eds.), The politics of inclusive development: interrogating the evidence. Oxford: Oxford University Press. doi:10.1093/acprof: oso/9780198722564.003.0001.

Ianchovichina, E., \& Lundstrom, S. (2009). Inclusive growth analytics: framework and application. Policy Research Working Papers, 4851. doi:10.1596/1813-9450-4851.

Innes, J., \& Booher, D. (2003). Collaborative policymaking: governance through dialogue. In M. Hajer \& H. Wagenaar (Eds.), Deliberative policy analysis: understanding governance in the network society. Cambridge: Cambridge University Press. doi:10.1017/CBO9780511490934.003.

Jarczewski, W., \& Kułaczkowska, A. (Eds.). (2019). Raport o stanie polskich miast: rewitalizacja. Retrieved 02.04.2020 from http://obserwatorium.miasta.pl.

Joshi, M. (2019). Report of HackerEarth's 400 global hackathons 2018 (infographic). Retrieved 02.04.2020 from https://www.hackerearth.com.

Keast, R., Mandell, M.P., Brown, K., \& Woolcock, G. (2004). Network structures: working differently and changing expectations. Public Administration Review, 64(3). doi:10.1111/j.1540-6210.2004.00380.x.

Klasen, S. (2010). Measuring and monitoring inclusive growth: multiple definitions, open questions, and some constructive proposals. ADB Sustainable Development Working Paper Series, 12.

Kożuch, B. (2007). Modele zarządzania publicznego. In T. Białas (Ed.), Dylematy i wyzwania wspótczesnego zarządzania organizacjami publicznymi. Gdynia: Wydawnictwo WSAiB im. E. Kwiatkowskiego.

López-Santana, M. (2015). The new governance of welfare states in the United States and Europe: between decentralization and centralization in the activation era. Albany: State University of New York Press.

McDermott, P. (2010). Building open government. Government Information Quarterly, 27(4). doi:10.1016/j.giq.2010.07.002.

Mello, L.D., \& Dutz, M.A. (Eds.). (2012). Promoting inclusive growth: challenges and policies. doi:10.1787/9789264168305-en. 
Miasto 2077. (2019). Raport: budżet obywatelski w polskich miastach 2019. Retrieved 02.04.2020 from https://www.miasto2077.pl.

Ministry of Economic Development. (2016). National urban policy 2023. Retrieved 27.03.2020 from https://www.gov.pl.

Mobility News. (2019). Hackathon city coders Ptock: maraton programistyczny już za nami. Retrieved 30.03.2020 from https://mobilitynews.pl.

Nelson, J. (2003). Grounds for alliance: overlapping interests of the poor and not so poor. In P.P. Houtzager, \& M. Moore (Eds.), Changing paths: international development and the new politics of inclusion. Ann Arbor: University of Michigan Press. doi:10.3998/mpub.17792.

Newman, J. (2001). Modernizing governance: new labour, policy and society. London: Sage. doi:10.4135/9781446220511.

NIK. (2019). Funkcjonowanie budżetów partycypacyjnych (obywatelskich). Retrieved 03.04.2020 from https://www.nik.gov.pl.

Nurudin, S.M., Hashim, R., Rahman, S., Zulkifli, N., Mohamed, A.S.P., \& Hamik, S.A. (2015). Public participation process at local government administration: a case study of the Seremban Municipal Council, Malaysia. Procedia: Social and Behavioral Sciences, 211. doi:10.1016/j.sbspro.2015.11.067.

OECD. (2014). All on board: making inclusive growth happen. Retrieved 16.01.2020 from https: //www.oecd.org.

OECD. (2015). Government at a glance 2015. doi:10.1787/gov_glance-2015-en.

OECD. (2016). Open government: the global context and the way forward. doi:10.1787/9789264268104-en.

Peter-Bombik, K., \& Szczudlińska-Kanoś, A. (2015). Zarządzanie partycypacyjne we wspólnotach lokalnych. Prace Naukowe Uniwersytetu Ekonomicznego we Wroctawiu, 391. doi:10.15611/pn.2015.391.08.

Pleczyński, W. (2019). Ptocki Hackathon: nad czym pracowali mtodzi informatycy. Retrieved 30.03.2020 from http://petronews.pl.

Ramos, R.A., Ranieri, R., \& Lammens, J.W. (2013). Mapping Inclusive Growth. IPC-IG Working Paper,105.

Ranieri, R., \& Ramos, R.A. (2013). Inclusive growth: building up a concept. IPC-IG Working Paper, 104.

Rauniyar, G., \& Kanbur, R. (2010). Inclusive development: two papers on conceptualization, application, and the ADB perspective. Cornell University, Department of Applied Economics and Management Working Papers, 57036.

Salamon, L. (2001). The new governance and the tools of public action: an introduction. Fordham Urban Law Journal, 28(5).

Samans, R., Blanke, J., Corrigan, G., \& Drzeniek Hanouz, M. (2017). The challenge of the century: inclusive growth and development. Rotman Management Magazine, 1 August.

Ustawa z dnia 9 października 2015 r. o rewitalizacji [Act of 9 October 2015 on revitalization] (Dz.U. 2015 poz. 1777) (Poland).

World Economic Forum. (2018). The inclusive development index 2018: summary and data highlights. Retrieved 18.01.2020 from http://www3.weforum.org. 


\section{Acknowledgements}

Author contributions: author has given an approval to the final version of the article.

Funding: this research was funded by the Nicolaus Copernicus University in Torun, Faculty of Economic Sciences and Management statutory sources. 


\section{Appendix}

Table 1.

Key indicators of inclusive development according to the World Economic Forum

\begin{tabular}{cccccc}
\hline \multicolumn{2}{c}{ Growth and development } & \multicolumn{2}{c}{ Inclusion } & \multicolumn{2}{c}{ Intergenerational equity and sustainability } \\
\hline \multirow{2}{*}{ GDP per capita } & labour & median & income & adjusted & dependency \\
& productivity & household income & Gini & net savings & ratio \\
employment & healthy life & poverty & wealth & public debt & carbon intensity \\
& expectancy & rate & Gini & (in \% of GDP) & of GDP \\
\hline
\end{tabular}

Source: Own preparation based on Samans et al. (2017, p. 23).

Table 2.

The 'New Governance' paradigm

\begin{tabular}{cc}
\hline Classical public administration & 'New Governance' \\
\hline program & tool \\
hierarchy & network \\
public vs. private & public \& private \\
command and control & negotiation and persuasion \\
management skills & enablement skills \\
\hline
\end{tabular}

Source: Own preparation based on Salamon (2001, p. 1624). 